\title{
Social Capital and Post-Secondary Decision-Making Alignment for Low-Income Students
}

\author{
Rod Missaghian (D)
}

check for

updates

Citation: Missaghian, Rod. 2021. Social Capital and Post-Secondary Decision-Making Alignment for Low-Income Students. Social Sciences 10: 83. https://doi.org/10.3390/ socsci10030083

Academic Editor: Nigel Parton

Received: 28 January 2021

Accepted: 23 February 2021

Published: 1 March 2021

Publisher's Note: MDPI stays neutral with regard to jurisdictional claims in published maps and institutional affiliations.

Copyright: (C) 2021 by the author. Licensee MDPI, Basel, Switzerland. This article is an open access article distributed under the terms and conditions of the Creative Commons Attribution (CC BY) license (https:// creativecommons.org/licenses/by/ $4.0 /)$.
Department of Sociology, University of Waterloo, Waterloo, ON N2L 3G1, Canada; rod.missaghian@uwaterloo.ca

\begin{abstract}
How is post-secondary decision-making influenced by the types of social capital students access? This study draws from interviews with 30 students in a low-income neighbourhood to examine who they turn to for post-secondary advice during the application process. Interactions with different ties and their influence on decision-making alignment, misalignment or uncertainty are explored. I find that students who report relying more on bonding (family and friends) social capital over (bridging) ties with school personnel demonstrate more misalignment in decision-making. In contrast, those who rely more on ties with school personnel exhibit more decision-making alignment. Many students whose proposed choices demonstrated alignment also lacked overall 'fit' and had unrealistic aspirations, except for a select few who reported close and consistent relationships with institutional agents. These findings contribute to the social capital literature examining the potential of institutional agents to help low-income students circumvent social stratification processes.
\end{abstract}

Keywords: social capital; decision-making; alignment; post-secondary

\section{Introduction}

The decision to attend college or university for youth transitioning directly from secondary school is both weighty and risky, as choosing the right program or institution can mean the difference between successful completion or dropping out (Rosenbaum 2011). The potential risks of not completing post-secondary and the consequences of student loans are more pronounced for students with fewer social and economic resources (Goldrick-Rab 2016); thus, lower-income students have less room for error when making decisions about the types of institutions and programs they apply to (Armstrong and Hamilton 2013; Cox 2016). Social scientists have explored the role of information and uncertainty in decision-making, working from the premise that some students operate with information deficits (Goyette 2008; Grodsky and Riegle-Crumb 2010; Sabates et al. 2011). A lack of information about post-secondary pathways can manifest as an overor under-estimation of the amount of education required for a particular job, or in other words, misalignment. Much of the work on alignment, however, consists of quantitative studies focusing on modeling predictive associations between decision-making beliefs and post-secondary enrollment decisions (Morgan et al. 2013) or labour market outcomes (Kim et al. 2019). Other research examines the relationship between mentorship ties and high school achievement (Erickson et al. 2009) or college application rates (Bryan et al. 2011). However, none of this work focuses on the relationship between social ties and their influence on helping shape beliefs and expectations about post-secondary pathways during the application process. This reflects a general lack of qualitative research that focuses on the social processes which inform educational decision-making behaviours.

Recent qualitative work that interviews students about the social ties that they turn to for post-secondary advice reveals important decision-making patterns for certain social groups. For example, Perez and McDonough (2008) find that ethnic minority students defer to close (bonding) ties within their own ethnic group, choosing post-secondary pathways close to home, or institutions that other family members have attended. Other researchers, 
like Hardie (2015, p. 256), note that working-class and poor students have "restricted networks", which cannot offer many resources to help with decision-making; thus, lowerincome students tend to rely on school personnel (bridging social capital), also referred to as institutional agents (see Stanton-Salazar 2010) to help them with decision-making. However, this research does not use an evaluative framework to assess the quality of decision-making, focusing exclusively on ties and less on the rationales students use to explain their decision-making.

This article uses Schneider and Stevenson's (1999) framework of "aligned ambition". Schneider and Stevenson (1999) argue that students who lack the ability to link their near-term educational plans with future labour market pathways are at a higher risk for "misalignment". Decision-making alignment, or "aligned ambition", occurs when students' educational expectations satisfy the educational requirements of their future occupational aspirations.) to address a central research question: how do ties with close family members (bonding) versus non-parental and school-based ties (bridging) influence post-secondary decisions? To answer this question, it draws from 30 in-depth interviews with students at Eastgate Secondary (Pseudonym) during the "search" stage (The 'search' stage refers to the period when students gather information and consult various sources to narrow down their post-secondary application set, whereas the choice stage involves making a final decision (see Hossler and Gallagher 1987 for information about this framework) of the decision-making life-course in situ (Svendsen 2006), to explore how the process unfolds in real-time. Much of the work in the decision-making literature also lacks a focus on students who live in the poorest neighbourhoods, with little social and economic resources, who are at the greatest risk for negative educational outcomes (Croninger and Lee 2001; Finn and Rock 1997; Galindo et al. 2017; Rush and Vitale 1994). Eastgate secondary is located in one of the poorest neighbourhods in the province of Ontario, thus serving as an ideal context to examine low-income student decision-making.

The aim of this research is to explore which types of social capital students rely on for advice in the decision-making process, and to examine the range and quality of decisions produced. The 'instrumentality' of social capital is often context dependent, as well as shaped by students' social class backgrounds, and the ties that are available to them in their networks. Thus, while patterns in decision-making associated with both bonding and bridging social capital ties are found, the use of the concept of 'fit' helps illustrate the various nuances in decision-making behaviour. This research finds that while students who report both bonding and bridging social capital can possess alignment, they do so while also demonstrating uncertainty and a lack of "fit"; their post-secondary application choices align with their stated career aspirations, but their goals are unrealistic. Thus, this research theorizes that alignment may only be useful when it is paired with consistent and close ties with institutional agents, who can help students choose programs that correspond with their educational achievement and career goals. This research contributes to the work of Stanton-Salazar (2010) and others (see Farmer-Hinton 2008; Stephan 2013; Schwartz et al. 2016) who stress the importance of mentoring relationships between low-income students and school personnel.

\section{Decision-Making Alignment and Social Capital}

Lareau and Cox (2011) use the concept of "fit" to describe the efforts of invested middle and upper middle-class parents in helping their kids choose a PSE (post-secondary education) institution that aligns with their academic and social skillsets. Implicit within their conceptualization of finding the right "fit" for children is that students without this type of direct intervention can be forced to make decisions on their own, and often with limited information. Students from more privileged backgrounds can count on their parents having more intimate understandings of the inner-workings of the PSE system, and can thus intervene on their behalf when they feel decisions do not "fit" well with their interests and capabilities. Where cultural capital theorists concentrate on the adaptation of daily and cultural practices to align with schooling requirements (Alon 2009; Aurini and 
Hillier 2018; Calarco 2014; Davies and Rizk 2018; Lareau 2011), other scholars have focused on the role that information deficits and uncertainty play in decision-making (see Goyette 2008; Morgan et al. 2013; Schneider and Stevenson 1999). Schneider and Stevenson's (1999) work on aligned ambition is the most well-known of these studies which focuses on the role of occupational plans on decision-making rationales.

Schneider and Stevenson (1999) warn that students can form unrealistic ambitions for postsecondary careers, based on limited information from their parents, as well as from a lack of access to school personnel. Without an informed understanding of how certain educational pathways can match their occupational goals, students could be making decisions in suboptimal conditions that can compromise the consistency of their decision-making (Morgan et al. 2013). Furthermore, they may be unaware how degree pathways align with their grades, goals and available financial means, making investments in education which are not good for them long-term. The costs of such miscalculations are more dire for students from low-income backgrounds. Other scholars, like Stanton-Salazar (2010), also illustrate the urgency of sound decision-making for low-income students, by stressing the importance of forming strong ties with school personnel. The role of school personnel, or "institutional agents" becomes extremely important for them, as they generally lack close ties with adults who can provide informed guidance about postsecondary pathways. Therefore, it is important to understand what kinds of ties students have within their networks, and their influence on the quality of decision-making.

Bonding and bridging social capital are two often cited categories in educational literature (Galindo et al. 2017), developed by Putnam (2001) to understand the different functions of social ties. Bonding social capital refers to ties formed with similar others, usually within close knit, and homogenous groups (Coleman 1988). Its function is to build cohesive ties, founded on trust and reciprocity. Bridging social capital, in contrast, moves the actor outside of their immediate networks, and is dependent on connections with people from different social circles; its function is to expand an individual's network, as well as access to resources. Bridging, or weak ties (see Granovetter 1995), can help individuals access novel information that can help them succeed. However, the concepts of bonding and bridging social capital have been critiqued for being "too instrumentalist about its effects" (Portes and Sensenbrenner 1993, p. 1346). Scholars have argued that the mechanisms and social structures that precede the emergence of social capital, and help shape it, can lead to positive and negative effects. Others have expanded on this critical approach, suggesting low-income and minority students are often prevented by the social structures (i.e., schools) they inhabit from activating available networks with teachers (Stanton-Salazar 1997).

\section{Bonding Social Capital}

Low-income and first-generation PSE students tend to rely on the advice of their family and friends, many of whom never attended PSE. In a mixed methods study with a sample of 17 first year Latina/o college students, Person and Rosenbaum (2006) find that they rely heavily on ties with their family and friends in their enrollment decisions. This also leads to students forming ethnic enclaves, with many Latina/o attending the same schools and acting as sources of support and information for one another. While this type of bonding social capital might seem advantageous for social support and assimilation purposes, it potentially limits the amount of information that students are exposed to.

Bonding social capital has been argued to be advantageous for students with networks comprised of friends with parents that have post-secondary educations (Carolan and Lardier 2018). However, less is known about the potential negative effects of bonding social capital, particularly for students from the poorest neighbourhoods. Navigating through postsecondary options without the proper guidance from schools and parental supports can often lead low-income students into impractical choices which can increase their chances for dropping out (Armstrong and Hamilton 2013; Lehmann 2007). While low-income parents provide moral support and encouragement which can lead to positive 
emotional outcomes for students, parents without post-secondary education are not able to provide informed, first-hand advice.

\section{Bridging Social Capital}

Bridging social capital connects us with ties outside our immediate social circles who can provide us with novel information and opportunities (Burt 2000). However, the influence of such ties for educational decision-making is something that has been missing from the literature. According to Stanton-Salazar (2010), working-class and minority youth lack ties to high-status adults who can offer them advice. Therefore, the teachers and other personnel that they encounter on a daily basis at school, thus present them with a potential source of high-status network contacts who can link them with other influential adults. The advice they offer can help empower low-income students to make effective decisions and counteract educational stratification.

Several researchers have used these insights to demonstrate the importance of institutional agents in shaping the educational outcomes of students from low-income communities. Stephan (2013) looks at the role of counselors as an important source of social capital for students, particularly from disadvantaged areas. She argues that low-income students can benefit immensely from one-on-one coaching from trained counselors, as they are less likely than their higher SES counterparts to seek out and receive such attention. Cates and Schaefle (2011) similarly find that targeted services for low-income college students, like mentoring, advising and summer programs improve outcomes. Ferguson (2018) finds that teachers who receive praise and gratitude from the low-income students they serve are more likely to continue on mentoring students well after the initial relationship is formed. Thus, along with initiating contact with institutional agents, students are well-served when they take steps to actively look for, and cultivate relationships with mentors who can help guide them (Holland 2010). Unfortunately, the literature is replete with evidence of low-income students' lack of cultural capital (Lareau and Cox 2011) and know-how (Schwartz et al. 2016) required to form and develop their own social networks.

\section{Canadian versus U.S. Education Systems}

To understand student decision-making in a Canadian context, it is important to highlight some of the distinguishing features of our system, particularly as it compares to the United States. Scholars have long acknowledged Canada as a persuasive counterfactual to the U.S., using their many similarities as an opportunity to compare and analyze distinctions (Siddiqi et al. 2009; Siddiqi et al. 2013). The Canadian postsecondary system is far less stratified than the U.S., with less disparity between the funding institutions receive at the top of the institutional hierarchy, versus those in the mid-to-lower tiers (Davies and Zarifa 2012). Canadian students have been said to place their decision-making emphasis on lucrative programmes within universities (Davies and Hammack 2005) as opposed to relying on institutional prestige and university rankings (Pizarro Milian and Rizk 2018). Costs associated with higher education, on average, are reported to be $40 \%$ higher in the United States; however, there is evidence that the threshold between lower-income students and tuition costs is lower in the U.S. because of more financial support for these students (Belley et al. 2014). The average cost of university tuition in Ontario for 2020-2021 is \$7938 (Statistics Canada 2021). This can be a significant cost for students at Eastgate, considering that over half of the population in the neighbourhood have an average household income of less than $\$ 50,000$ annually. It is thus not surprising that post-secondary enrolment for Eastgate students can be up to $15 \%$ lower than school board averages, depending on the year.

\section{Data and Methods}

Eastgate Secondary was chosen as the research site because of its location in an area of the city that has been labelled by municipal authorities as a "priority neighbourhood". This category was created by the city to help develop policies that address many of the social 
problems that are challenges for this community. For example, the median family income is $30 \%$ lower than the municipal average, while the percentage of adults with bachelor degrees is $75 \%$ lower. There is also a higher concentration of government subsidized housing, and the condition of many of these homes are poor, with vandalism and graffiti being consistent problems.

The school and area in which it is located have been in the local news repeatedly over the past two decades for issues relating to gang violence, and the risks to children in the community growing up in an environment of urban "decay" and "disorder" (see Cyr 2014 , p. 11). Eastgate is also consistently ranked at the top of the school boards' annual index measuring external challenges, such as median family income, and their influence on negative educational outcomes. These factors made Eastgate an ideal or "information-rich" site, chosen specifically for the insights it would promise with regards to the postsecondary decision-making of low-income students (Palinkas et al. 2015, p. 534).

My sample of interviewees can be classified on a continuum ranging from low-income to working-class. Most of the students' parents work in either blue collar jobs, as labourers, or in poorly paid and insecure jobs in the food service industry (for an explanation of class categorization, see Thompson et al. 2016). Only two students fell outside the working class/low-income category, as they have parents employed in professional or managerial roles (see Appendix A). Black students represent the third largest visible minority in the school board after South and East Asians, but at Eastgate, they are the overwhelming majority, with South and East Asians making up a majority of the remaining student body.

A strategic and purposive sampling strategy (see Miles et al. 2014) was employed to recruit students in grade 12 English and mathematics courses, which serve as prerequisites for a majority of post-secondary programs in Canada. Purposive sampling, which is a standard in qualitative research, is used when the researcher "decides what needs to be known and sets out to find people who are willing to provide the information" (Etikan et al. 2016 , p. 2) These classes were intentionally targeted for recruitment, as they were likely to contain graduating students with post-secondary aspirations. The final sample included (18) females and (12) males which closely approximates the $62 \%$ of female undergraduates reported in federal census data (Turcotte 2011). A total of 30 students were interviewed, 20 of whom were Black, but from a variety of ethnic ancestries; the remaining 10 were from various South, West and Southeast Asian countries (see Appendix B). While the sample of students in this study is diverse, I focus only on social class, as the small sample size limits controlling for race and gender differences.

All students were either first- or second-generation immigrants, while the great majority $(26 / 30)$ were first-generation postsecondary students. Four students had parents with postsecondary education, but who received their degrees outside of Canada (e.g., the United States, and Europe), thus their knowledge of the Canadian PSE system is likely limited. More specifically, 65 percent of mothers and fathers have "unknown" or less than high school education. The interviewees who answered "other" or "unknown" for parental education are from impoverished or war-torn countries like Afghanistan or Somalia. When probed further during interviews about their parents' education, these students admitted that their education was so low it was difficult to say when they ceased attending school. Some students have stay at home mothers (7), while others are unemployed, cannot work or are on social assistance (see Appendix A). Just over half of the students reported living in the same household with both their mother and father (see Appendix B).

Semi-structured interviews were conducted with 30 students at Eastgate Secondary between October and December in 2018, very close to the January 2019 college and university application deadlines. The collection of surveys prior to interviews further triangulated data collection, along with the presence of college and university enrollment data provided by the school's guidance counselors. On the surveys, students indicated their age, race, citizenship status, as well as the occupation and education levels obtained by their parents. Students were also asked about their self-reported academic averages since grade 9, as well as whether the majority of their classes were in academic versus applied streams 
(In Ontario, streaming was introduced in 1999 with the intention of giving students choices between applied or academic courses; applied being more hands-on and practical, while academic consisting of more theoretical courses designed to prepare students for university. The practice is slowly being phased out, as of July 2020). The modal grade averages amongst the 30 students were 70 to 80 percent, while the majority of students also reported taking academic and university stream classes.

Interviews lasted between $30 \mathrm{~min}$ and $60 \mathrm{~min}$, averaging $35 \mathrm{~min}$; students received a $\$ 15$ gift card for participating. All interviews were audio recorded; careful notes were taken periodically throughout to complement transcription. All interviews were conducted by the author, a male of West Asian heritage, whose personal attire resembled a middle ground between teacher and student. The author was introduced as a former teacher who had worked at Eastgate Secondary 5 years prior, as well as a graduate student.

Students were asked about their aspirations and plans for postsecondary, adults they were close to or could turn to for advice, and what types of school resources they used to help them make decisions and why. This line of questioning is very similar to recent research that has sought to understand the role of social capital for low-income student decision making (see Hardie 2015). Participants were asked to describe a range of their adult ties outside of the school context, including potential ties to neighbors, community members, family members and adults in other settings. Questions were asked about the frequency of contact with each tie, how long they have known them, as well as their educational background and current occupation. Participants were asked to recall the nature of the conversations with their ties, specifically with respect to their upcoming applications to college and university. Not surprisingly, most students did not report having a lot of ties that could offer them advice. For the most part, the students talked about good advice they had received, close relationships they had formed with a mentor, which was usually a teacher, guidance counselor or other school personnel.

\section{Analysis}

Interviews were transcribed and imported into QSR NVivo. A two-phase coding strategy was used. The initial coding was organized around the thematic categories of the interview schedule (i.e., Aspirations, Social Capital and Decision-Making), and nodes that fell within those categories were created. During this stage, rich descriptions surrounding when and how students formed their postsecondary and career aspirations, and who was involved in those decisions, were coded into more distinct nodes. The node "Aspirations" for example, focused on questions relating to students' future plans, their selection of PSE choices, and parental influence in helping to shape them. Student responses to questions pertaining to "Social Capital", were coded according to answers pertaining to their ties to adults. Ties with other students were gleaned through a separate question about what students' friends planned to do after postsecondary. When students mentioned their parents, siblings, relatives and close friends as sources of advice about PSE, these responses were coded as "Bonding" social capital. The other ties that students mentioned were mainly teachers, guidance counselors, principals and other personnel located in the school, or ties with adults in organizations that were established for them through participation in school programming. These ties were coded as "bridging social capital" and ties with school agents were also coded under the node "Institutional Agents".

In the second phase of coding, initial codes were streamlined into theoretically informed nodes, using an in-depth reading of the prevalent theories that inform student decision-making and social capital. This captured the decision-making logics (how they rationalize their actions) and the ways in which ties to different adults in their lives helped shape student choices. It was also in this phase where certain disparate codes were aligned with new thematical categories such as "Alignment" and "Fit": two theoretical perspectives that emerged after individual interviews were re-read to glean new insights and to confirm and disconfirm initial coding choices. The process of using pre-established theories or concepts and allowing open coding and the emergence of new nodes was part of a 
simultaneous (deductive) and (inductive) strategy. Several of the findings sections focus on student accounts of their career aspirations and rationales for wanting to attend certain institutions. The sections draw from data coded under the master node of "Alignment", its parent and grandchild nodes, to capture key aspects behind the role of social capital on decision-making. Different ways in which students make "Certain" "Vague" "Aligned" and "Misaligned" educational choices and their rationales behind decisions also became visible (for an excellent overview of coding, see Saldaña 2015).

Finally, individual interviews were revisited to draw simple counts of the average number of ties, the percentage with PSE and whether students knew someone in their desired profession (see Appendix B). Counts were produced by transferring answers from transcripts into an excel file which kept track of quantifiable data. Once the total number of ties were counted, transcripts were examined for qualitative features of ties with adults, like how well they knew individuals and why they felt comfortable relying on them. Responses and the counts allowed me to consider how the amount, quality and nature of ties with adults helped shape student perceptions about their enrollment process and impending decisions.

\section{Findings}

Interviews with students revealed patterns of alignment and misalignment in decisionmaking, and were connected with the types of ties (bonding or bridging) they reported relying on for advice. Overall, students at Eastgate reported very few ties on average (3.85), with some reporting as few as a single individual that they could rely on for advice (one student, Karl, reported not consulting with anyone about his post-secondary choices). Students who reported half or more of their ties as comprising bonding social capital, such as close relatives, friends or parents, tended to exhibit misalignment in their decision-making logics. Students who reported more than half of their ties as comprising bridging social capital, with institutional agents either in their school or in other contexts, overwhelmingly exhibited alignment in decision-making. Alignment was assessed by asking students what they wanted to study in post-secondary, as well as what career they hoped to attain. If the amount of education required by the occupation exceeded the expected level of education reported, then the student was coded as "undereducation" (or misaligned). However, the in-depth interviews revealed inconsistencies in student responses. While having ties with bridging social capital influenced alignment between educational and occupational aspirations, students also made comments which suggested their choices may not be a good "fit" with their academic performance and stated interests. For example, Nassar's university program choice (criminology) aligned well with his career aspiration of police officer; he also reported relying exclusively on bridging ties for advice (school librarian and guidance counselor). However, despite alignment with his stated intention, Nassar aspired to a competitive program with below average grades. In fact, he mentioned being in a credit-recovery program, which suggests he had academic struggles, and being interested in other careers like the military or "business". This inconsistency, or uncertainty, suggests that simply having alignment with stated preferences may not be conducive to future success. Low-income students may require help from institutional agents, but this research shows that the quality of those relationships requires further investigation.

In subsequent sections, examples are provided about of how bonding and bridging social capital tended to produce different decision-making logics. Parents and close relatives offered advice without providing details about how a specific school and program would "fit" with a student's goals and personality. Rather, the advice seemed superficial, lacking any criteria that could match student grades and interests with specific programs and/or institutions. In contrast, the advice from institutional agents helped students choose programs based on this type of information; when students relied more on these ties, they usually ended up with alignment. For example, crosstabulations examining the relationship between reported ties and misalignment reveal these overall patterns. Table 1 
shows that $87.5 \%$ of students who indicated having a higher proportion of bridging social capital demonstrated decision-making alignment in their decision-making. However, even when students reported having bridging ties, they did not consult them frequently and this led to uncertainty and inconsistencies in decision-making logics.

Table 1. Type of social capital and decision-making alignment—crosstabulation.

\begin{tabular}{cccc}
\hline & Alignment & Misalignment & Total \\
\hline Bonding & 2 & 5 & 7 \\
& $28.6 \%$ & $71.4 \%$ & $100 \%$ \\
Bonding/Bridging & 2 & 4 & 6 \\
Bridging & $33.3 \%$ & $66.6 \%$ & $100 \%$ \\
& 14 & 2 & 16 \\
None & $87.5 \%$ & $12.5 \%$ & $100 \%$ \\
Column Total & & 1 & 1 \\
& 18 & $100 \%$ & $100 \%$ \\
& $60 \%$ & 12 & $30 \%$ \\
\hline
\end{tabular}

Bonding = students with more than $\frac{1}{2}$ reported ties bonding. Bonding/Bridging = students with $\frac{1}{2}$ reported ties bridging and $\frac{1}{2}$ bonding. Bridging $=$ students with more than $\frac{1}{2}$ reported ties bridging. A single student reported no ties.

\subsection{Bonding Social Capital}

Students at Eastgate that relied more on bonding social capital for advice about post-secondary, generally had more misaligned decision-making. Of the 13 students that reported ties with bonding social capital (see Table 1), 9/13 (69\%) of them demonstrated misaligned decision-making rationales. While the students at Eastgate had very close ties with their friends, both in the school, and former students who had gone on to postsecondary, these interactions did not yield useful information about prospective institutions and programs. The advice they received was normally encouragement, but lacked informed details that could help students both align their decisions with career aspirations, and choose a program and institution that fit with their academic ability, personality and social goals.

Bonding social capital amongst students at Eastgate was represented by friends or family who were new post-secondary students, or adult family ties (usually parents) without any postsecondary experience. Along with lacking PSE experience, only 10/30 $(33.3 \%)$ of the ties reported by students were with adults who were employed in the occupation that they aspired towards (see Appendix B). Interviews revealed that bonding social capital did not yield any novel information about the post-secondary system. Rather, the advice students received, particularly from their parents, was more aspirational in nature. Their parents wanted them to attend institutions with high prestige, even if their aspirations were divorced from knowledge about the best fit for their child. For example, Robert who was applying for competitive engineering programs talked about the type of advice he received from his parents:

I guess it's completely my choice, but the actual university, they do like kind of based on reputation, right? So no matter what I say, they always tell me that if I get accepted to City University, I should go there because it has the best reputation, right?

This type of generic advice, that was based on perceptions, but lacking in specific insider information about specific programs and institutional features was common amongst the advice students received from family members. Students like Kendra, for example, would share that they heard about a community college from cousins, and that it was "a good college with lots of people there inspired to become a better person". However, when they were probed to share specific details about the strength of a program and its fit with their education and career goals, their answers lacked these details. For some students, the language barrier and cultural divide between their parents' country of origin and Canada 
posed barriers to advice giving. As Farzeen, a first-generation student from Afghanistan, shared: "They told me go for whatever you would like to do, we support you no matter what. If there is any kind of help I would need from my parents, although they're not really good with English."

While bonding social capital from parents and close friends did not provide students with insider information about the system, it did serve useful purposes for some students, particularly those with siblings in PSE. Students like Robert, for example, had siblings that acted as examples of what they could aspire towards. Robert's brother was a thirdyear engineering student at a prestigious university in the province. When asked about who he could turn to for advice he had this to say: "Probably the biggest one, my older brother... He's currently a computer engineering student himself. And that's probably the one I talk to the most in terms of my decision, and I guess advice in general, just because he's older than me." Not coincidentally, Robert had his brother's university as one of his top four choices. This is another example of the positive influence that bonding social capital can play in raising the aspirations of low-income students. Close bonds allowed for students to receive advice about postsecondary, but that advice sometimes came from parents, relatives and friends without PSE (38\%) (see Appendix B). This type of generic advice, or moral support, to pursue their goals, while also lacking in specific details, could nevertheless serve to motivate these students to apply. Recent research in the U.S. suggests that this type of moral encouragement can lift the post-secondary aspirations of low-income students (Roksa et al. 2020). However, with regards to aiding students to gain information about their programs and institutions that move beyond status perceptions, and popular sentiments, advice from bonding social capital did not achieve this for students at Eastgate.

\subsection{Bonding Social Capital: Aligned but Uncertain}

Not all students who reported bonding social capital demonstrated misalignment in their decision-making, yet they were still vulnerable to uncertainty or a lack of "fit" in postsecondary choices. Table 2 shows that a high percentage $(72.3 \%)$ of students that satisfied the definitional requirements of decision-making alignment also exhibited uncertainty when their decision-making was considered as a whole. Uncertainty, or "lack of fit", was represented by explicit statements of being "unsure" about a potential pathway, or when students demonstrated inconsistencies in decision-making logics. For example, Amina was a student who aspired towards a career as an editor, which was perfectly aligned with her educational expectations of a BA in English; two of her three reported advice ties were with family members. She reported relying on family and friends more than her guidance counselor to make a program choice that aligned with her career aspirations. However, her interview revealed information that suggested that a BA in English may not have been the best fit with her interests. Amina shared that English was mainly chosen, because she received high grades:

Uh, what inspired me was like, I like English and I always like kind of excelled well in it since like, I would say Grade 10. And um, I just assumed that was the way to go. But then I wondered, like would I want to be writing my own stuff or should I be editing other people's because I'm not very good at writing myself, to be honest.

Amina's choice was aligned with her career aspirations, yet she was still "not sure", and felt that "it seemed" like a good choice because she got a good mark in English that year. It appears inconsistent for a student who claims that writing is not a strength to be pursuing a career in that area. Amina aspired to attend one of the most prestigious universities in the country, as well as pursuing a major that depends on superior writing skills for success. Had she began thinking about this earlier, and had more consistent advice from institutional agents, it is interesting to think about how her choices might have been influenced. 
Table 2. Decision-making alignment and uncertainty—crosstabulation.

\begin{tabular}{cccc}
\hline & \multicolumn{3}{c}{ Uncertainty } \\
\hline \multirow{3}{*}{ Alignment } & No & Yes & Total \\
& 5 & 13 & 18 \\
Misalignment & $27.8 \%$ & $72.3 \%$ & $100 \%$ \\
& 3 & 9 & 12 \\
Column Total & $27.3 \%$ & $81.8 \%$ & $100 \%$ \\
& 8 & 22 & 30 \\
& $26.7 \%$ & $73.3 \%$ & $100 \%$ \\
\hline
\end{tabular}

Sandra was one of two students who reported an equal amount of bonding and bridging ties, while demonstrating alignment and lack of fit. She wanted to be a doctor, and was planning to apply for general science programs, a common path towards medical school. She also added that she had chosen a potential career in medicine because "she had always wanted to help people." She went on to describe how in eighth grade she had thought about being a teacher but changed her mind "because I want to finish school and then go into a job where I know there's jobs." Interestingly enough, Sandra never indicated a genuine love for medicine as a reason for wanting to pursue the profession. At the time of the interview, Sandra had indicated receiving grades that ranged from the 60 s all the way to the 80 s.

In Canada, acceptance into a Science undergrad program is extremely competitive, with an overall average of 80 (A minus) generally being the bare minimum requirement, although there are some programs that accept students with a minimum of 70 (B minus). Sandra's borderline grades and her goal of medicine suggest that she was never "cooled off" by any institutional gatekeepers (see Clark 1960). Although she cited her guidance counselor as a tie, her interactions were reported as being infrequent. She reported only having a single appointment since school had begun, with applications due two months from when the interview took place: "I'm gonna try and book another appointment so I can talk to her and say, "Okay, am I at a point where I should take an emergency backup and go to college or should I continue?" Sandra was aware that her grades were not good enough for a career in medicine and she was already looking to "hedge" (see Gabay-Egozi et al. 2010), by sharing her openness to the possibility of attending community college. It seems that the teaching pathway fit more with Sandra's comments about wanting to help people, along with her overall academic preparation.

Choosing a postsecondary pathway is not an easy task, and as Taifa, a female student of Somali heritage explained, sometimes you go through "1000 careers" before deciding on which one to pursue: "I'm not joking. I thought of a speech pathologist, a pediatrician, a professor. I thought of 1000 different careers." Interestingly enough, Taifa, like many other students at Eastgate, seemed very confused about what path to pursue. She expressed an interest in both a nursing career and one as a writer. Her justification for wanting to be a nurse was that she was "very interested in helping people and just having a career that's assisting people who are in need, who are sick, something like that." But in the same moment, she expressed an interest in "writing books" because she would not have to work as a "Doctor in an office all day ... you're not on your feet, you're just in a small space." Taifa also mentioned not having met with her guidance counselor: "She's kind of busy right now. She's very busy. She's going on different college fairs, university fairs. All of this. I'm gonna eventually meet with her sometimes, but I'm not too sure when." It seems clear that had many of these students met more frequently with their school guidance counselor, a key institutional agent in their lives, they would have more access to accurate information that would prevent them from misaligned and uncertain decision-making.

\subsection{Closer Bridging Ties: Students with Alignment and Fit}

Access to ties that could provide accurate and reliable information about postsecondary choices was important to students who exhibited more aligned decision-making 
logics. The networks of students at Eastgate were, on average, few in number and bridging ties normally constituted teachers and guidance counselors in the school. Unlike the students who reported infrequent contact with institutional agents, students with both aligned decision-making and fit were characterized by closer and more frequent contact. However, there were only a handful of these students (5) that were interviewed (see Table 2), and three of them are featured in this section.

In contrast to the aforementioned Sandra, whose ambition for medical school was unrealistic, Cynthia, a recent immigrant from Jamaica, seemed more aware of her current academic abilities and set her sights on a more achievable goal. Cynthia planned to apply to a concurrent education program at a university that offered a dual degree in education, along with a certificate in early childhood education (Concurrent education programs allow students to simultaneously get their degree and teacher certification within the same credential, without having to pursue an extra post-graduate degree in education). Cynthia described only needing "an average of like 70-75\%" which was consistent with her current academic performance. She stated not being "good" at the sciences, and felt more comfortable taking liberal arts classes and pursuing a career as a teacher. Cynthia was one of four students in my sample who belonged to an after-school program that was sponsored by a local not-for-profit, that aimed to help students from this community get private tutoring as well as one-on-one postsecondary counseling. Students in this program would regularly meet with a program counselor to discuss their postsecondary aspirations and plans. Cynthia discussed meeting regularly with the organizer of this program: "Yesterday, we were speaking to him about universities and colleges. There's this group in the school called Student Achievement, and he's the founder of it. I went to him for advice."

Unlike other students who were unclear about what programs and schools they would apply to, Cynthia seemed to have more clarity, as well as specific information about the programs that interested her. Cynthia attended a local university fair and acquired specific information from the recruiters about her program:

There were people specialized in these booths, who were telling us, giving us more information about programs. It's like only five years I have to study, and I get a degree and teaching certificate. I wouldn't have to go to teacher's college.

Most students in this study did not possess specialized information about programs and which schools in the province offered various options. Cynthia's access to bridging social capital in the form of this program coordinator linked her to private college counseling that she would otherwise have not received from her family and friends, even though her original aspiration was motivated by the example of her stepmother: "Because my step mom ... She does this ECE (Early Childhood Education) program at Forest College (Pseudonym)." However, when asked about how involved her parents were in her educational decision-making, Cynthia shared that they were "laid back", "hands-off," and when it came to sit "down to view the different universities and see their programs and stuff like that, it's just me doing all the research."

Farzeen, mentioned earlier, knew that relying on her parents could not get her the specialized information she needed. Her parents struggled with the English language and had received limited education from their birth country. For her parents to even become aware of what Farzeen had planned, she would have to go in depth and give a lot of background information: "I would have to explain the background, before I even explain what it is." Farzeen had a keen sense that in order for her to learn more about her future possibilities, she would have to reach out to an extended network:

As I have left a lot of things behind, and what I've learned from my parents is that connection plays a big role in life, and learning from others, it's a really good thing, it's not a bad thing. There may be different aspects of it, different perspectives, different opinions, but you gain something from each experience. 
Farzeen was one of a handful of students interviewed that relied exclusively on institutional agents for key advice about postsecondary decision-making. She had a total of 10 adults from whom she received advice, well above the reported average of 3.85, and had indicated receiving very close mentorship from several of them. The students, like Farzeen, who reported relying exclusively on institutional agents for advice, seemed to have a more unique pathway ahead of them. Farzeen was also the only student who planned to take a year off, and seemed acutely aware of what she was, and was not capable of academically:

I know a lot of people are like, "You don't have to be sure and you change different paths," but for me, I haven't found something particular that I actually wanna say I'm interested in. Laws is just one of the options that I was provided with in high school. First, I was looking to do medical field, but then I recognized that I'm really bad with sciences ... so I dropped the medical field and I pursued laws. So far, law is going well, I don't have any complaints but it's not something that I'm like, "Okay, I love this. I wanna do this for the future."

Farzeen's level of self-awareness was rare amongst the students in this sample. Understanding her limitations, changing trajectories, and then having the courage to take a year off to volunteer and solidify her choices are things that can be attributed to her close and consistent ties with a range of institutional agents.

Diana was another first-generation immigrant student in this cohort, who like Farzeen, reported relying on absolutely no family or friends as a source of advice about postsecondary planning. All of the contacts that she mentioned as sources of advice were comprised of institutional agents in the school: teachers, guidance counselors and the principal, along with other personnel outside the school who ran affiliated programs. Diana's prospective choice of universities was completely unique to those of other students at Eastgate. While most students chose local universities, Diana was one of five students who planned to apply to schools more than $2 \mathrm{~h}$ driving distance away from her neighbourhood. Her top two school choices were smaller, less prestigious universities according to national rankings, but extremely highly rated for their undergraduate programs, and specifically their 'forensic psychology' programs which are unique amongst Canadian higher education institutions. Diana's choices were 'niche' when compared to the rest of her cohort, and it appears that her choices were informed by more research, personal exploration and guidance from institutional agents. Diana was enrolled in several school sponsored academic programs, notably, a dual-credit program with a local university. Diana describes a conversation with her guidance counselor who directed her to the dual credit program:

When I wasn't sure about what exactly I wanted to take in terms of program, I just knew my interests, so he just said, "There's a program that gets you into a university course, it builds your knowledge and your skills, and you also get to choose a course that is in your interests, to actually see if you're interested in it ..."

Diana had consistent visits with her guidance counselor and claims to have "known his schedule" which allowed her to have "more time to talk to him." Diana, unlike many of the other students, seemed to have nuanced information about both her program of choice as well as other finer details about program offerings. During her interview, she was probed by the author to see if she understood the difference between forensic psychology and criminology to which she replied: "It's more science than social science but it has the psychology, as well. So, it's like both science and social science." When asked about how her particular program will help her achieve her career ambitions, she exhibited knowledge about specific features of the program:

Well, the specific schools that I'm going to apply to, if I get into it, they each have co-op placement and ... What's the other word? Internships. So, that will allow me to actually be on the job and get the on the job feel and see.

These examples are illustrative of both decision-making alignment, but also institutional fit; students who formed closer ties with institutional agents were better able to 
understand their prospective programs, and pair this information with self-knowledge about their interests, goals and academic preparation.

\section{Discussion}

While we know that students from low-income backgrounds often lack high-status ties to adults that can help them navigate the postsecondary enrollment process (StantonSalazar and Dornbusch 1995), existing research says little about how non-parental ties influence the choice process at pivotal time points. Instead, research has tended to focus on quantitative data looking at individual level alignment (Morgan et al. 2013; Sabates et al. 2011), or the influence of parent-child ties on decision-making (Cheng and Starks 2002; Kim and Schneider 2005). There is still a dearth of qualitative research that looks at decision-making and social capital ties for low-income students, at the critical juncture prior to application deadlines. Existing qualitative work looks at the types of relational ties that working-class students (see Hardie 2015) and specific ethnic subgroups in the U.S. like Latina/o (see Perez and McDonough 2008) and African Americans (see Farmer-Hinton and Adams 2006) depend on when making educational plans. However, most of the current literature on social capital and educational decision making lacks a concerted focus on the poorest neighbourhoods, instead focusing on middle- and working-class neighbourhoods (see Hardie 2015; Lareau 2011).

This article focused on the types of social ties low-income students reported relying on for decision-making advice, in one of the poorest neighbourhoods in Ontario. Results showed that students, on average, possessed few ties, and these consisted of a mix between bonding and bridging social capital. Social capital had different influences on decisionmaking alignment, with the frequency and intensity of visits with an institutional agent being related to possessing both alignment and institutional fit. Of the 18/30 students interviewed who demonstrated alignment, through both bonding and bridging social capital ties, only five of those moved beyond surface level alignment. These students, while also meeting the definitional requirements of alignment, exhibited a deeper and informed knowledge of the post-secondary system, and had realistic aspirations that matched their educational achievement. They also reported frequent visits with various school personnel, and felt comfortable asking them for advice. It seemed that their relationships were with teachers and guidance counselors who acted as mentors, as opposed to single serve advisors.

These findings have important consequences for the way low-income students form ties with institutional agents. While many cited an institutional agent as one of the ties they could rely on for advice, their interviews suggested infrequent interaction. Scholars looking at the cultural transmission of school-appropriate behaviours and interactions with teachers suggest that low-income students have difficulty approaching teachers and making meaningful connections with them (Calarco 2014; Jack 2016; Yee 2016). While this was not the focus of this study, my interviews with students at Eastgate demonstrated that the quality of their relationships with institutional agents was reflective of their own knowledge about the PSE system in Ontario. Those few students that demonstrated both alignment and fit were students that possessed multiple and close ties with institutional agents they reported seeing on a regular basis. Some students belonged to after-school programs where they received targeted help, and this helped them choose programs and institutions that were realistic with their academic performance and overall career goals. These findings highlight the complexity of bonding and bridging social capital, as interaction between ties often happens on a continuum. They also highlight the enormous responsibility of institutional agents in low-income neighbourhoods to transmit timely and accurate information.

Why were certain students able to develop contacts with institutional agents in their school? Did they possess certain help-seeking capacities? Future research could perform longitudinal ethnographic research to learn more about how students interact with institutional agents at schools like Eastgate. In the absence of observations and interviews with 
the ties students reported, we can only speculate on what those capacities are. While the single school used to sample students for interviews represents the most extreme case of a low-income school in this particular urban Canadian environment, it might not be representative of the city as a whole. In addition, qualitative research with smaller, nonrandom samples is not generalizable. This study was limited to low-income first-generation post-secondary students, and did not include those from middle-class backgrounds whose parents attended post-secondary. Future research might want to consider sampling from multiple schools, with varying degrees of student achievement and families from different socio-economic backgrounds.

\section{Conclusions}

By examining the decision-making process during the critical months before postsecondary applications are due, we were able to understand how various ties, particularly those with institutional agents, inform decision-making alignment. Several researchers have similarly focused on the importance of institutional agents in shaping the educational outcomes of students from low-income communities. Stephan (2013) evaluates a college coaching program, with targeted counseling for low-income students, and argues these interventions can positively influence enrolment outcomes; however, the focus here, as with other similar research is on various transition and completion metrics (see Cates and Schaefle 2011; Holland 2010), not on evaluating the types of decisions that are made. Ferguson's (2018) research fills an important gap in the present study, by interviewing teachers in low-income neighbourhoods about their experiences interacting with students. That research identified reciprocal relationships as being fundamental to forming closer mentorship ties between students and teachers. While this research established the importance of mentorship ties with institutional agents as critical to developing alignment and fit in decision-making, we learned little about how those relationships were formed. A missing piece in this research is the perspectives of the teachers and guidance counselors that students cited as ties.

Many students cited either their mother, father or both parents, as sources of advice for post-secondary decision-making. However, the advice they reported receiving served a different, yet still valuable purpose; it mainly consisted of moral encouragement and emotional support. Recent research has shown that this type of support can positively serve the aspirations of low-income college students and increase their sense of belonging (Roksa et al. 2020). However, this does not necessarily solve the issue of lower rates of PSE completion for low-income students, both in the U.S. (Bowen et al. 2009), and in Canada (Childs et al. 2017). Recent research has suggested that aligned ambition in high school increases educational attainment in post-secondary (Schmitt-Wilson and Faas 2016). While this research only focuses on a single moment in time, it helps expand on quantitative studies looking at the association between aligned ambition and outcomes. It does so by showing that alignment can often be superficial if not paired with institutional fit, which is something that involves more long-term reflection on future goals, which students from low-income background traditionally do not engage with (Lareau 2000; Armstrong and Hamilton 2013; Hamilton et al. 2018).

Relationships to weak ties have been argued to be a key factor in adults being able to access novel information about labor market opportunities (Granovetter 1995). In this study, weak ties, which mainly consisted of relationships with school personnel (institutional agents) play a similar role as weak ties in adult job networks, providing students with information that their own networks cannot. However, unsurprisingly, these ties with school personnel did not always lead to alignment and decision-making certainty. Social capital theorists have been critical of the traditions lack of focus on the socio-structural limitations that can lead to restricted personal networks for underrepresented students (Portes 1998; Stanton-Salazar 2010). This research study points to Stanton-Salazar's (1997, 2010) work on low-income and minority youth social capital, and recommends that more work needs to be done to understand how "pivotal moments" (see Espinoza 2011, p. 2) 
can create enduring bonds between low-income students and caring institutional agents. How initial ties with institutional agents are formed needs to be explored, but also tracked over time to understand their lasting effects. Thus, when low-income students are able to identify and capitalize on opportunities with institutional agents they can "overcome the odds" (Stanton-Salazar 2010, p. 40), by tapping into an important resource, helping them align decision-making and choose programs that best fit their overall needs. This can have significant policy implications for how schools approach developing mentorship opportunities for students in Ontario. Policy makers can invest in better understanding how to develop school sponsored activities and programs that pair students with staff and other leaders in the community. Some of the students interviewed discussed belonging to "Specialist High Skills Majors". This is an Ontario Ministry of Education funded program to help students work with school staff on creating a plan that can help them transition to college, university and other post-secondary options. Programs like these, as well as after-school programs run by charitable and not-for-profit organizations, which several students in this study participated in, should be further studied to see how students interact with adults in these contexts.

Funding: This research received no external funding.

Institutional Review Board Statement: This study was approved by the University of Waterloo's Institutional Review Board \#22804, April 2018.

Informed Consent Statement: Informed consent was obtained from all subjects involved in the study.

Data Availability Statement: No new data were created or analyzed in this study. Data sharing is not applicable to this article.

Conflicts of Interest: The author declares no conflicts of interest.

Appendix A. Parental Education and Occupation

\begin{tabular}{|c|c|c|c|c|}
\hline $\begin{array}{l}\text { Student } \\
\text { Name }\end{array}$ & $\begin{array}{l}\text { Father's } \\
\text { Education }\end{array}$ & $\begin{array}{l}\text { Mother's } \\
\text { Education }\end{array}$ & $\begin{array}{c}\text { Father's } \\
\text { Occupation }\end{array}$ & Mother's Occupation \\
\hline Farzeen & Other & High School & Shipping & Stay At Home \\
\hline Amina & High School & High School & Taxi Driver & Stay At Home \\
\hline Maryam & Bachelors & High School & Truck Manager & Bus Driver \\
\hline Hani & Vocational & High School & Truck Driver & Stay At Home \\
\hline Mike & College & Don't Know & Cannot Work & Factory Worker \\
\hline Nassar & Don't Know & Don't Know & $\mathrm{N} / \mathrm{A}$ & $\mathrm{N} / \mathrm{A}$ \\
\hline Diana & Don't Know & Don't Know & Labourer & Small Business \\
\hline Cynthia & Vocational & Vocational & Carpenter & $\mathrm{N} / \mathrm{A}$ \\
\hline Hallima & Don't Know & Don't know & Labourer & Food Service \\
\hline Sharon & High School & High School & Unemployed & Factory Worker \\
\hline Rose & Don't Know & High School & N/A & Waitress \\
\hline Karl & $\mathrm{N} / \mathrm{A}$ & High School & $\mathrm{N} / \mathrm{A}$ & $\mathrm{N} / \mathrm{A}$ \\
\hline Adaeze & Don't Know & Masters & Technician & Elementary Teacher \\
\hline Ivey & No Contact & Don't Know & Estranged & Unemployed \\
\hline Kendra & Don't Know & College & Farmer & Packaging \\
\hline Sandra & Don't Know & Don't Know & Factory Worker & Stay At Home \\
\hline Taifa & High School & Don't Know & Packaging & Stay At Home \\
\hline Christine & Don't know & High School & Truck Driver & Stay At Home \\
\hline Samantha & High School & Don't Know & Don't Know & Unemployed \\
\hline Ron & High School & High School & Mechanic & Unemployed \\
\hline Steven & Deceased & High School & Deceased & Security Guard \\
\hline Fatima & High School & High School & Truck Driver & Food Service \\
\hline Martyna & Don't Know & Other & Unemployed & Factory Worker \\
\hline DeMarcus & Don't Know & College & Small Business & Cashier \\
\hline Kyle & Don't Know & High School & Security Guard & Airport Security \\
\hline Saadi & Masters & Bachelors & Navy & Factory Worker \\
\hline Soheil & Don't Know & Don't Know & Car Sales & Sales \\
\hline Gupal & Deceased & Bachelors & $\mathrm{N} / \mathrm{A}$ & Nurse \\
\hline Robert & Other & Other & Driving Instructor & Factory Worker \\
\hline Steven & College & College & Childcare & Small Business \\
\hline
\end{tabular}

$\mathrm{N} / \mathrm{A}$ responses for parental occupation were later probed and a majority of them represented a parent/s that were on social assistance. 


\section{Appendix B. Descriptive Statistics}

\begin{tabular}{ll}
\hline Family Structure & \\
\hline Living With Parent (s) & \\
Yes & 16 \\
No & 14 \\
Student Born in Canada & \\
Yes & 21 \\
No & 9 \\
Ethnic and Racial Background & \\
Black (Caribbean) & 10 \\
Black (Africa) & 10 \\
South Asian & 5 \\
Southeast Asian & 4 \\
Central Asian & 1 \\
First-Generation Postsecondary & \\
Yes & 26 \\
No & 4 \\
Parents Born in Canada & \\
Neither & 30 \\
Educational Aspiration & \\
Graduate/Professional School & 6 \\
Four Year University & 15 \\
Two-Three-year college & 8 \\
Other & 1 \\
Occupational Aspiration & \\
High Professional & 11 \\
Low Professional & 13 \\
Non-professional & 1 \\
Mixed/Unsure & 5 \\
Mean number of ties & 3.85 \\
\% of ties with some PSE & 62 \\
Know someone in desired job \% & 33 \\
Uncertain about PSE choice \% & 73 \\
Chose local college or university \% & 80 \\
N & 30 \\
High professional = Doctor, Engineer & Black (Caribbean)-Jamaica, Grenada \\
Low professional = Nurse, Police Officer & Black (Africa)-Somalia, Nigeria, Gambia \\
Mixed = Entrepreneur, IT & South Asian (i.e., Afghanistan, India, Pakistan) \\
& Southeast Asian (i.e., Cambodia, Vietnam) \\
\hline & Central/West Asian-Tajikistan \\
\hline & \\
& \\
&
\end{tabular}

\section{References}

Alon, Sigal. 2009. The evolution of class inequality in higher education: Competition, exclusion, and adaptation. American Sociological Review 74: 731-55. [CrossRef]

Armstrong, Elizabeth A., and Laura T. Hamilton. 2013. Paying for the Party. Cambridge: Harvard University Press.

Aurini, Janice, and Cathlene Hillier. 2018. Re-Opening the black box of educational disadvantage: Why we need new answers to old questions. In Education in a New Society: Renewing the Sociology of Education. Chicago: University of Chicago Press, pp. 309-33.

Belley, Philippe, Marc Frenette, and Lance Lochner. 2014. Post-secondary attendance by parental income in the US and Canada: Do financial aid policies explain the differences? Canadian Journal of Economics/Revue Canadienne D'économique 47: 664-96. [CrossRef]

Bowen, William G., Matthew M. Chingos, and Michael S. McPherson. 2009. Crossing the Finish Line: Completing College at America's Public Universities. Princeton: Princeton University Press.

Bryan, Julia, Cheryl Moore-Thomas, Norma L. Day-Vines, and Cheryl Holcomb-McCoy. 2011. School counselors as social capital: The effects of high school college counseling on college application rates. Journal of Counseling Development 89: 190-99. [CrossRef]

Burt, Ronald S. 2000. The Network Structure of Social Capital. Research in Organizational Behavior 22: 345-423. [CrossRef]

Calarco, Jessica McCrory. 2014. Coached for the classroom: Parents' cultural transmission and children's reproduction of educational inequalities. American Sociological Review 79: 1015-37. [CrossRef]

Carolan, Brian V., and David T. Lardier. 2018. Adolescents' Friends, Parental Social Closure, and Educational Outcomes. Sociological Focus 51: 52-68. [CrossRef]

Cates, Jennifer T., and Scott E. Schaefle. 2011. The Relationship Between a College Preparation Program and At-Risk Students' College Readiness. Journal of Latinos and Education 10: 320-34. [CrossRef]

Cheng, Simon, and Brian Starks. 2002. Racial Differences in the Effects of Significant Others on Students' Educational Expectations. Sociology of Education 75: 306-27. [CrossRef]

Childs, Stephen E., Ross Finnie, and Felice Martinello. 2017. Postsecondary student persistence and pathways: Evidence from the YITS-A in Canada. Research in Higher Education 58: 270-94. [CrossRef]

Clark, Burton R. 1960. The "cooling-out" function in higher education. American Journal of Sociology 65: 569-76. [CrossRef]

Coleman, James S. 1988. Social Capital in the Creation of Human Capital. American Journal of Sociology 94: 95-120. [CrossRef]

Cox, Rebecca D. 2016. Complicating conditions: Obstacles and interruptions to low-income students' college "choices". The Journal of Higher Education 87: 1-26. 
Croninger, Robert G., and Valerie E. Lee. 2001. Social Capital and Dropping out of High School: Benefits to At-Risk Students of Teachers' Support and Guidance. Teachers College Record 103: 548-81. [CrossRef]

Cyr, Darren. 2014. Physical Graffiti and School Ecologies: A New Look at 'Disorder', Neighbourhood Effects And School Outcomes. Ph.D. dissertation, McMaster University, Hamilton ON, Canada. Available online: http://hdl.handle.net/11375/16461 (accessed on 10 September 2019).

Davies, Scott, and Floyd M. Hammack. 2005. The Channeling of Student Competition in Higher Education: Comparing Canada and the U.S. The Journal of Higher Education 76: 89-106. [CrossRef]

Davies, Scott, and Jessica Rizk. 2018. The three generations of cultural capital research: A narrative review. Review of Educational Research 88: 331-65. [CrossRef]

Davies, Scott, and David Zarifa. 2012. The stratification of universities: Structural inequality in Canada and the United States. Research in Social Stratification and Mobility 30: 143-58. [CrossRef]

Erickson, Lance D., Steve McDonald, and Glen H. Elder Jr. 2009. Informal mentors and education: Complementary or compensatory resources? Sociology of Education 82: 344-67. [CrossRef] [PubMed]

Espinoza, Roberta. 2011. Pivotal Moments: How Educators Can Put All Students on the Path to College. Cambridge: Harvard Education Press.

Etikan, IIker, Sulaiman A. Musa, and Rukayya S. Alkassim. 2016. Comparison of convenience sampling and purposive sampling. American Journal of Theoretical and Applied Statistics 5: 1-4. [CrossRef]

Farmer-Hinton, Raquel L. 2008. Social capital and college planning: Students of color using school networks for support and guidance. Education and Urban Society 41: 127-57. [CrossRef]

Farmer-Hinton, Raquel L., and Toshiba L. Adams. 2006. Social Capital and College Preparation: Exploring the Role of Counselors in a College Prep School for Black Students. Negro Educational Review 57: 101-16.

Ferguson, Sherelle. 2018. Ask Not What Your Mentor Can Do for You ... : The Role of Reciprocal Exchange in Maintaining Student-Teacher Mentorships. Sociological Forum 33: 211-33. [CrossRef]

Finn, Jeremy D., and Donald A. Rock. 1997. Academic Success Among Students At Risk for School Failure. Journal of Applied Psychology 82: 221-34. [CrossRef] [PubMed]

Gabay-Egozi, Limor, Yossi Shavit, and Meir Yaish. 2010. Curricular Choice: A Test of a Rational Choice Model of Education. European Sociological Review 26: 447-63. [CrossRef]

Galindo, Claudia, Mavis Sanders, and Yolanda Abel. 2017. Transforming Educational Experiences in Low-Income Communities: A Qualitative Case Study of Social Capital in a Full-Service Community School. American Educational Research Journal 54: 140-63. [CrossRef]

Goldrick-Rab, Sara. 2016. Paying the Price: College Costs, Financial Aid, and the Betrayal of the American Dream. Chicago: University of Chicago Press.

Goyette, Kimberly A. 2008. College for some to college for all: Social background, occupational expectations, and educational expectations over time. Social Science Research 37: 461-84. [CrossRef]

Granovetter, Mark. 1995. Getting a Job: A Study of Contacts and Careers. Chicago: University of Chicago.

Grodsky, Eric, and Catherine Riegle-Crumb. 2010. Those who choose and those who don't: Social background and college orientation. The ANNALS of the American Academy of Political and Social Science 627: 14-35. [CrossRef]

Hamilton, Linda, Josipa Roksa, and Kelly Nielsen. 2018. Providing a 'leg up': Parental involvement and opportunity hoarding in college. Sociology of Education 91: 111-31. [CrossRef]

Hardie, Jessica Halliday. 2015. The Best Laid Plans: Social Capital in the Development of Girls' Educational and Occupational Plans. Social Problems 62: 241-65. [CrossRef]

Holland, Nicole E. 2010. Postsecondary Education Preparation of Traditionally Underrepresented College Students: A Social Capital Perspective. Journal of Diversity in Higher Education 3: 111-25. [CrossRef]

Hossler, Don, and Karen S. Gallagher. 1987. Studying Student College Choice. A Three Phase Model and the Implications for Policy Makers. College and University 2: 207-21.

Jack, Anthony Abraham. 2016. No harm in asking: Class, acquired cultural capital, and academic engagement at an elite university. Sociology of Education 89: 1-19. [CrossRef]

Kim, Doo Hwan, and Barbara Schneider. 2005. Social Capital in Action: Alignment of Parental Support in Adolescents' Transition to Postsecondary Education. Social Forces 84: 1181-206. [CrossRef]

Kim, Soobin, Christopher Klager, and Barbara Schneider. 2019. The effects of alignment of educational expectations and occupational aspirations on labor market outcomes: evidence from NLSY79. The Journal of Higher Education 90: 992-1015. [CrossRef]

Lareau, Annette. 2000. Home Advantage: Social Class and Parental Intervention in Elementary Education. Lanham, Boulder, New York and Oxford: Rowman \& Littlefield Publishers.

Lareau, Annette. 2011. Unequal Childhoods: Class, Race, and Family Life, 2nd ed. Berkeley, Los Angeles and London: University of California Press.

Lareau, Annette, and Amanda Cox. 2011. Social Class and the Transition to Adulthood. In Social Class and Changing Families in an Unequal America. Edited by Marcia J. Carlson and Paula England. Stanford: Stanford University Press, pp. $134-64$.

Lehmann, Wolfgang. 2007. Choosing to Labour? School-Work Transitions and Social Class. Montreal and Kingston: McGill-Queen's University Press. 
Miles, Matthew B., Michael A. Huberman, and Johnny Saldaña. 2014. Qualitative Data Analysis: An Expanded Sourcebook, 3rd ed. Thousand Oaks: Sage Publications.

Morgan, Stephen L., Theodore S. Leenman, Jennifer J. Todd, and Kim A. Weeden. 2013. Occupational plans, beliefs about educational requirements, and patterns of college entry. Sociology of Education 86: 197-217. [CrossRef]

Palinkas, Lawrence A., Sarah M. Horwitz, Carla A. Green, Jennifer P. Wisdom, Naihua Duan, and Kimberly Hoagwood. 2015 Purposeful sampling for qualitative data collection and analysis in mixed method implementation research. Administration and Policy in Mental Health and Mental Health Services Research 42: 533-44. [CrossRef] [PubMed]

Perez, Patricia A., and Patricia M. McDonough. 2008. Understanding Latina and Latino College Choice: A Social Capital and Chain Migration Analysis. Journal of Hispanic Higher Education 7: 249-65. [CrossRef]

Person, Ann E., and James E. Rosenbaum. 2006. Chain Enrollment and College Enclaves: Benefits and Drawbacks of Latino College Students' Enrollment Decisions. New Directions for Community Colleges 133: 51-60. [CrossRef]

Pizarro Milian, Roger, and Jessica Rizk. 2018. Do university rankings matter? A qualitative exploration of institutional selection at three southern Ontario universities. Journal of Further and Higher Education 42: 1143-55. [CrossRef]

Portes, Alejandro. 1998. Social capital: Its origins and applications in modern sociology. Annual Review of Sociology 24: 1-24. [CrossRef]

Portes, Alejandro, and Julia Sensenbrenner. 1993. Embeddedness and immigration: Notes on the social determinants of economic action. American Journal of Sociology 98: 1320-50. [CrossRef]

Putnam, Robert D. 2001. Bowling Alone: The Collapse and Revival of American Community. New York: Simon \& Schuster.

Roksa, Josipa, Denise Deutschlander, and Sarah E. Whitley. 2020. Parental Validation, College Experiences, and Institutional Commitment of First-Generation and Low-Income Students. Journal of Student Affairs Research and Practice, 1-15. [CrossRef]

Rosenbaum, James E. 2011. The Complexities of College For All: Beyond Fairy-Tale Dreams. Sociology of Education 84: 113-17. [CrossRef]

Rush, Sheila, and Patrick A. Vitale. 1994. Analysis For Determining Factors That Place Elementary Students At Risk. The Journal of Educational Research 87: 325-33. [CrossRef]

Sabates, Ricardo, Angel L. Harris, and Jeremy Staff. 2011. Ambition gone awry: The long-term socioeconomic consequences of misaligned and uncertain ambitions in adolescence. Social Science Quarterly 92: 959-77. [CrossRef]

Saldaña, Johnny. 2015. The Coding Manual for Qualitative Researchers. Thousand Oaks: Sage.

Schmitt-Wilson, Sarah, and Caitlin Faas. 2016. Alignment of educational and occupational expectations influences on young adult educational attainment, income, and underemployment. Social Science Quarterly 97: 1174-88. [CrossRef]

Schneider, Barbara, and David Stevenson. 1999. The Ambitious Generation: America's Teenagers, Motivated but Directionless. New Haven: Yale University Press.

Schwartz, Sarah E., Stella S. Kanchewa, Jean E. Rhodes, Evan Cutler, and Jessica L. Cunningham. 2016. I Didn't Know You Could Just Ask: Empowering Underrepresented College-Bound Students to Recruit Academic and Career Mentors. Children and Youth Services Review 64: 51-59. [CrossRef]

Siddiqi, Arjumand, Daniyal Zuberi, and Quynh C. Nguyen. 2009. The role of health insurance in explaining immigrant versus non-immigrant disparities in access to health care: Comparing the United States to Canada. Social Science Medicine 69: 1452-59. [CrossRef]

Siddiqi, Arjumand, India J. Ornelas, Kelly Quinn, Daniyal Zuberi, and Quynh C. Nguyen. 2013. Societal context and the production of immigrant status-based health inequalities: a comparative study of the United States and Canada. Journal of Public Health Policy 34: 330-44. [CrossRef] [PubMed]

Stanton-Salazar, Ricardo D. 1997. A Social Capital Framework for Understanding the Socialization of Racial Minority Children and Youths. Harvard Educational Review 67: 1-41. [CrossRef]

Stanton-Salazar, Ricardo D. 2010. A Social Capital Framework for The Study of Institutional Agents and Their Role in The Empowerment of Low-Status Students and Youth. Youth Society 43: 1066-109. [CrossRef]

Stanton-Salazar, Ricardo D., and Sanford M. Dornbusch. 1995. Social Capital and The Reproduction of Inequality: Information Networks Among Mexican-Origin High School Students. Sociology of Education 68: 116-35. [CrossRef]

Statistics Canada. 2021. 2016/17 to 2020/21 Canadian and International Tuition Fees by Level of Study. Available online: https: / / doi.org/10.25318/3710004501-eng (accessed on 28 January 2021).

Stephan, Jennifer L. 2013. Social Capital and the College Enrollment Process: How Can a School Program Make a Difference? Teachers College Record 115: 1-39.

Svendsen, Gunnar L. 2006. Studying Social Capital In Situ: A Qualitative Approach. Theory and Society 35: 39-70. [CrossRef]

Thompson, William E., Joseph V. Hickey, and Mica L. Thompson. 2016. Society in Focus: An Introduction to Sociology. Lanham: Rowman \& Littlefield.

Turcotte, Martin. 2011. Intergenerational Education Mobility: University Completion in Relation to Parents' Education Level. Canadian Social Trends 92: 37-43.

Yee, April. 2016. The unwritten rules of engagement: Social class differences in undergraduates' academic strategies. The Journal of Higher Education 87: 831-58. 